OPEN ACCESS

Edited by:

David Cameron Wraith, University of Birmingham,

United Kingdom

Reviewed by:

Michael Croft

La Jolla Institute for Allergy and Immunology (LJI), United States

Michael Levy,

Johns Hopkins University,

United States

*Correspondence:

Abdelhadi Saoudi

abdelhadi.saoudi@inserm.fr

Specialty section

This article was submitted to

Multiple Sclerosis and

Neuroimmunology,

a section of the journal

Frontiers in Immunology

Received: 27 July 2018 Accepted: 27 September 2018 Published: 25 October 2018

Citation:

Bernard I, Sacquin A, Kassem S, Benamar M, Colacios C, Gador M Pérals C, Fazilleau N and Saoudi A

(2018) A Natural Variant of the Signaling Molecule Vav1 Enhances Susceptibility to Myasthenia Gravis and Influences the T Cell Receptor Repertoire. Front. Immunol. 9:2399, doi: 10.3389/fimmu.2018.02399

\section{A Natural Variant of the Signaling Molecule Vav1 Enhances Susceptibility to Myasthenia Gravis and Influences the T Cell Receptor Repertoire}

\section{Isabelle Bernard, Antoine Sacquin, Sahar Kassem, Mehdi Benamar, Céline Colacios, Mylène Gador, Corine Pérals, Nicolas Fazilleau and Abdelhadi Saoudi *}

Centre de Physiopathologie de Toulouse Purpan, Université de Toulouse, UPS, Inserm, CNRS, Toulouse, France

The guanine nucleotide exchange factor Vav1 is essential for transducing $T$ cell receptor (TCR) signals and plays an important role in T cell development and activation. Previous genetic studies identified a natural variant of Vav1 characterized by the substitution of an arginine $(\mathrm{R})$ residue by a tryptophane $(\mathrm{W})$ at position 63 (Vav1 ${ }^{\mathrm{R} 63 \mathrm{~W}}$ ). This variant impacts Vav1 adaptor functions and controls susceptibility to T cell-mediated neuroinflammation. To assess the implication of this Vav1 variant on the susceptibility to antibody-mediated diseases, we used the animal model of myasthenia gravis, experimental autoimmune myasthenia gravis (EAMG). To this end, we generated a knock-in (KI) mouse model bearing a $\mathrm{R}$ to $\mathrm{W}$ substitution in the Vav1 gene (Vav1 ${ }^{\mathrm{R} 63 \mathrm{~W}}$ ) and immunized it with either torpedo acetylcholine receptor (tAChR) or the a146-162 immunodominant peptide. We observed that the Vav1 ${ }^{\mathrm{R} 63 \mathrm{~W}}$ conferred increased susceptibility to EAMG, revealed by a higher AChR loss together with an increased production of effector cytokines (IFN- $\gamma$, IL-17A, GM-CSF) by antigen-specific CD4 ${ }^{+} \mathrm{T}$ cells, as well as an increased frequency of antigen-specific $\mathrm{CD}^{+}{ }^{+} \mathrm{T}$ cells. This correlated with the emergence of a dominant antigen-specific T cell clone in $\mathrm{KI}$ mice that was not present in wild-type mice, suggesting an impact on thymic selection and/or a different clonal selection threshold following antigen encounter. Our results highlight the key role of Vav1 in the pathophysiology of EAMG and this was associated with an impact on the TCR repertoire of AChR reactive T lymphocytes.

Keywords: myasthenia gravis, $\mathrm{T}$ cells, Vav1, animal models, $\mathrm{T}$ cell repertoire

\section{INTRODUCTION}

Myasthenia gravis (MG), a disabling neuromuscular disease, is a $\mathrm{T}$ cell-dependent, B cellmediated autoimmune disease in which autoantibodies directed against antigens located at the neuromuscular junction (NMJ) cause defective neuromuscular transmission (1-3). Acetylcholine receptor $(\mathrm{AChR})$ is the main autoantigen of MG. Antibodies directed against AChR are found in $85 \%$ of MG patients and are likely responsible for loss of functional receptors and destruction of the post-synaptic membrane (4). In addition, antibodies against other NMJ proteins, such as muscle specific kinase (MUSK) (5) and low-density lipoprotein receptor-related protein 4 (LRP4) (6, 7), are 
found in a proportion of patients negative for anti-AChR antibodies. Current therapies of MG need to be ameliorated, notably concerning disease progression and there is therefore an urgent need for the identification of new therapeutic targets. A better understanding of the etiology of MG and the pathways leading to disease induction may provide rational bases for developing new treatments. In this regard, experimental autoimmune MG (EAMG) models have been instrumental over the years for a better understanding of the pathophysiological role of specific autoantibodies and $\mathrm{T}$ helper lymphocytes, because they closely mimic human $\mathrm{MG}$ in its clinical and immunopathological manifestations. EAMG can be induced by immunizing mice with AChR purified from the electric organs of the Torpedo ray $(8,9)$. In EAMG, it has been shown that anti-AChR antibodies bind to the AChR at the neuromuscular junction, activate complement and accelerate AChR destruction, thereby leading to neuromuscular transmission failure and fatigable muscle weakness.

The etiology of MG is still unknown but it is assumed that this non-inherited disease results from complex interactions between multiple genotypes of low penetrance and environmental factors. Indeed, a large number of genes conferring significant increments in MG risk have been identified $(10,11)$, but their functional relevance in MG pathogenesis remains elusive. Most of MG risk genes are involved in immune system functions. They involve the major histocompatibility complex (MHC) class II locus, the protein tyrosine phosphatase non-receptor type 22 (PTPN22) $(12,13)$, the TNFAIP3 interacting protein 1 (TNIP1) (14), the cytotoxic T-lymphocyte-associated protein 4 gene (CTLA4) (15, 16) and the guanine nucleotide exchange factor (GEF) VAV1 (17). VAV 1 is an essential molecule for transducing T cell antigen receptor (TCR) signals and therefore plays a critical role in the development and activation of T cells (18-22). Following TCR engagement, VAV1 is recruited to the transmembrane adaptor protein LAT via the GADS and SLP76 adaptors, leading to the phosphorylation of its acidic domain by LCK. The functional importance of VAV1 has been revealed by several studies, both in developing and mature $\mathrm{T}$ cells, which showed that VAV1deficient mice exhibited a strong impairment in thymic selection and harbored mature $\mathrm{T}$ cells that displayed reduced proliferation, activation and cytokine production (19). This phenotype results from a decrease in TCR-induced signaling that involve $\mathrm{Ca}^{2+}$ mobilization, as well as activation of ERK MAP kinases, of phosphoinositide-3-kinase (PI3K), of the serine-threonine kinase $\mathrm{AKT}$, and of transcription factors, such as nuclear factor of activated T cells (NFAT) and nuclear factor $\kappa$ B (NF- $\kappa$ B) (22-24). Although VAV1 acts primarily as a GEF, its scaffolding role is also important for $\mathrm{T}$ cell activation $(25,26)$. The GEF activity of VAV1 is necessary for T cell development and for the optimal activation of T cells, including signal transduction to RAC1, AKT, and integrins. In contrast, VAV1 GEF activity is not required for TCR-induced $\mathrm{Ca}^{2+}$ flux, activation of ERK and PKD1, and cell polarization. Thus, many critical events involved in $\mathrm{T}$ cell

Abbreviations: CFA, complete Freund's adjuvant; EAMG, experimental autoimmune myasthenia gravis; tAChR, torpedo acetylcholine receptor; NMJ, neuromuscular junction. activation are mediated by either the GEF or the scaffolding activities of VAV1.

Previous genetic studies performed by our team identified a non-synonymous SNP in the Vav1 gene that leads to the substitution of an arginine (R) by a tryptophane (W) residue. This natural variant of $\operatorname{Vav} 1\left(\operatorname{Vav}^{\mathrm{R} 63 \mathrm{~W}}\right)$ is characterized by an increased activation rate, together with a strong reduction of its protein expression levels. This variant displays reduced adaptor functions but normal GEF activity $(26,27)$. By generating a knock-in mouse model (Vav1 ${ }^{\mathrm{R} 63 \mathrm{~W}} \mathrm{KI}$ ), we showed that Vav1 ${ }^{\mathrm{R} 63 \mathrm{~W}}$ leads to a reduced susceptibility to $\mathrm{T}$ cell-mediated central nervous system inflammation (EAE) induced by $\mathrm{MOG}_{35-55}$ immunization (26). Herein, we sought to determine the involvement of this Vav1 variant in the susceptibility to antibodymediated diseases, using an EAMG model. We show that Vav1 ${ }^{\mathrm{R} 63 \mathrm{~W}}$ conferred increased susceptibility to EAMG, revealed by a greater AChR loss. This augmented susceptibility was associated with increased frequency of antigen specific $\mathrm{CD} 4^{+} \mathrm{T}$ cells and emergence, in $\mathrm{KI}$ mice, of a dominant antigen-specific $\mathrm{T}$ cell clone that was not present in wild-type mice. Thus, our data suggest that Vav1 influences susceptibility to myasthenia gravis and this was associated with an impact on TCR repertoire of AChR self-reactive T cells.

\section{MATERIALS AND METHODS}

\section{Animals}

Eight to ten-weeks-old mice harboring the $\operatorname{Vav1} 1^{\mathrm{R} 63 \mathrm{~W}}$ variant (international strain designation C57BL/6-Vav1 ${ }^{\mathrm{tm} 2 \mathrm{Mal}}$ ) (26) and their littermate controls were used in this study. All mice were housed under specific pathogen-free conditions at the INSERM animal facility (US-006; accreditation number A-31 55508 delivered by the French Ministry of Agriculture to perform experiments on live mice). All experimental protocols were approved by a Ministry-approved ethics committee (CEEA-122) and are in compliance with the French and European regulations on care and protection of the Laboratory Animals (EC Directive 2010/63).

\section{Purification of $\mathrm{tAChR}$ and Induction of Experimental Autoimmune Myasthenia Gravis}

Torpedo AChR (tAChR) was purified from electric organs of Torpedo marmorata by affinity chromatography on a conjugate of neurotoxin coupled to agarose, as previously described (28). To induce EAMG, mice were immunized with $10 \mu \mathrm{g}$ of $\mathrm{tAChR}$ emulsified in CFA (Sigma-Aldrich) in a total volume of 100 $\mu l$, injected s.c. at the tail base. Four weeks after the first immunization, mice received a booster injection with $10 \mu \mathrm{g}$ of tAChR emulsified in CFA in a total volume of $200 \mu$ l, injected in the flanks and at the tail base. Control mice received an equal volume of PBS in CFA $(100 \mu$ l then $200 \mu \mathrm{l})$.

\section{Measurement of Muscle AChR Content}

Three weeks after the second immunization, the concentration of AChR present in total body musculature was measured by RIA using muscle detergent extracts, as previously described (29). 
Briefly, the frozen carcasses were homogenized and membranebound proteins were extracted with PBS containing 2\% Triton X-100 (Sigma-Aldrich). Aliquots $(250 \mu \mathrm{l})$ of each extract were labeled in triplicate with $2 \times 10^{-9} \mathrm{M}^{125} \mathrm{I}$-labeled $\alpha$-bungarotoxin (Amersham; sp. act., $>150 \mathrm{Ci} / \mathrm{mmol}$ ) incubated overnight with an excess of rat anti-AChR antibody and precipitated by goat anti-rat IgG. The concentration of AChR in muscle was expressed as moles of ${ }^{125} \mathrm{I}$-labeled $\alpha$-bungarotoxin precipitated per gram of muscle and the percentage of AChR content per mouse was calculated by comparison with that found in control adjuvantimmunized mice.

\section{RIA for Serum Anti-mouse AChR Antibodies}

Sera from each mouse were prepared from bleeding collected 3 weeks after the secondary immunization. The concentration of Abs reactive to mouse AChR was determined in individual sera by RIA, as previously described (29). Briefly, mouse AChR was extracted from leg muscles and labeled with $2 \times 10^{-9} \mathrm{M}$ ${ }^{125}$ I-labeled $\alpha$-bungarotoxin (Amersham). A dilution range of serum samples was incubated overnight with $200 \mu$ l of labeled mouse AChR. Antibody-AChR complexes were captured by adding an excess of rabbit anti-mouse IgG (Sigma-Aldrich). The radioactivity of the complexes was measured in a gamma counter. Values of ${ }^{125}$ I-labeled $\alpha$-bungarotoxin-AChR pelleted in the presence of normal mouse serum were subtracted from the assay values. Corrections for inter-assay variability were made based on serial dilutions of an EAMG standard control serum pool tested in each assay. The antibody titers were expressed as moles of ${ }^{125}$ I-labeled $\alpha$-bungarotoxin binding sites precipitated per liter of serum.

\section{Cell Culture and Cytokine Measurement}

WT or Vav1 ${ }^{\mathrm{R} 63 \mathrm{~W}} \mathrm{KI}$ were immunized with $10 \mu \mathrm{g}$ of tAChR or $50 \mu \mathrm{g}$ of AChR $\alpha 146-162$ peptide in CFA. Para-aortic and inguinal draining lymph node cells (LNC) were harvested 9 days later. LNC were cultured at $5 \times 10^{5}$ cells/well in 96 well-culture plates (TPP) in RPMI 1640 culture medium (Sigma-Aldrich) containing $10 \%$ of FCS, sodium pyruvate, non-essential amino acids, L-glutamine, penicillin-streptomycin and $2 \times 10^{-5} \mathrm{M} \beta$ mercaptoethanol. Cultures were incubated in the presence of various concentrations of tAChR protein or AChR $\alpha 146-162$ immunodominant peptide (GeneCust). For cytokine analysis, supernatants were collected after 48 to $72 \mathrm{~h}$ of culture. IFN- $\gamma$ and IL-17A were quantified by ELISA. 96 well-plates were coated for $2 \mathrm{~h}$ at $37^{\circ} \mathrm{C}$ followed overnight at $4^{\circ} \mathrm{C}$ with capture antibodies in carbonate buffer $0.05 \mathrm{M} \mathrm{pH}$ 9.6. Culture supernatants or standards were incubated $1 \mathrm{~h}$ at $37^{\circ} \mathrm{C}$. The plates were then incubated for $1 \mathrm{~h}$ with a secondary biotinylated antibody specific for each cytokine, followed by $45 \mathrm{~min}$ incubation with streptavidin-phosphatase alkaline at $37^{\circ} \mathrm{C}$. Finally, plates were revealed by phosphatase alkaline substrate and absorbance was measured at $405 / 650 \mathrm{~nm}$. Antibodies used for ELISA were: purified anti-mouse anti-IFN- $\gamma$ (AN18), purified anti-mouse IL-17A (TC11-18H10), biotin anti-mouse IFN- $\gamma$ (XMG1.2), biotin anti-mouse IL-17A (TC11-8H4). These antibodies were purchased from BD Biosciences. Recombinant cytokines were used as standards (Peprotech). The production of GM-CSF and IL-13 was assayed using Cytometric Bead Array cytokine kit (BD Biosciences). For T cell proliferation assays, cells $\left(5 \times 10^{5}\right.$ cells/well) were pulsed with $1 \mu \mathrm{Ci}$ of $[3 \mathrm{H}] \mathrm{TdR}(40 \mathrm{Ci} / \mathrm{nmol}$; Radiochemical Centre) during the last $16 \mathrm{~h}$ of culture before harvesting on glass fiber filter. Incorporation of $[3 \mathrm{H}] \mathrm{TdR}$ was measured by direct counting using an automated beta plate counter (Matrix ${ }^{\mathrm{TM}} 9600$; Packard Instrument). The intracellular analysis of cytokine synthesis was performed on LNC stimulated $72 \mathrm{~h}$ with tAChR protein or $\alpha 146-162 \mathrm{AChR}$ peptide. Then, cells were stimulated with PMA $(100 \mathrm{ng} / \mathrm{ml})$ plus ionomycin $(1 \mu \mathrm{g} / \mathrm{ml})$ during the last $4 \mathrm{~h}$ in the presence of GolgiPlug (BD Biosciences). Cells were then harvested, washed, stained with Fixable Viability Dye eFluor780 (eBioscience) for exclusion of dead cells, before staining surface markers with PerCP antiTCR (H57-597) and BV510 anti-CD4 (RM4-5). After fixation and permeabilization with staining buffer (eBioscience), cells were incubated $30 \mathrm{~min}$ with APC-labeled anti-IFN- $\gamma$ (XMG1.2), FITC-labeled anti-IL-17A (TC11-18H10), PE-labeled anti-GMCSF (MP1-22E9) antibodies, or isotype controls. Data were collected on a LSRII flow cytometer (BD Biosciences) and analyzed using the FlowJo software (TreeStar).

\section{Phenotypic Analysis and Cell Sorting}

Cell suspensions were prepared in PBS/2\% FCS, 5mM EDTA. Organs were dissociated, filtered and treated with Fc block (2.4G2) for $10 \mathrm{~min}$. To track antigen-specific CD4 ${ }^{+} \mathrm{T}$ cells, cells were incubated with PE-AChR I-A ${ }^{\mathrm{b}}$ tetramer $\left(7 \mu \mathrm{g} \mathrm{ml}^{-1}\right)$ and APC anti-CXCR5 (REA 215, Miltenyi Biotec, 1:50) for $2 \mathrm{~h}$ at room temperature. The tetramer AChR I-A ${ }^{b}$ was obtained from the NIH Tetramer core facility. After tetramer staining, cells were washed and incubated on ice for $45 \mathrm{~min}$ with fluorophore labeled mAbs. The following $\mathrm{mAbs}$ from $\mathrm{BD}$ Biosciences were used: anti-CD138 (281-2), anti-CD4 (RM4-5), anti-CD8 $\alpha$ (536.7), anti-CD95 (15A7), anti-CD3 $\varepsilon$ (500A2). The following mAbs from eBioscience were used: anti-B220 (RA3-6B2), anti-GL-7 (GL-7), anti-CD44 (IM7), anti-Foxp3 (FJK-16). For intracellular staining, cell suspensions were fixed and permeabilized using BD Fixation/Permeabilization kit. Before permeabilization cells were stained. The cells were then suspended with Fixable Viability Dye eFluor506 (eBioscience) for exclusion of dead cells. Data were collected on a BD LSRII/Fortessa (BD Biosciences) and analyzed using FlowJo software (Tree Star). Sorting of tAChRspecific $\mathrm{CD}^{+}{ }^{+} \mathrm{T}$ cells was performed using FACSARIA-SORP (BD Biosciences).

\section{RNA Extraction, cDNA Synthesis and Quantitative PCR}

RNA was isolated with the RNeasy Mini Kit (Quiagen). cDNA was reverse transcribed with the High-Capacity cDNA Reverse Transcription Kit (Applied Biosystems). Quantitative PCR amplifications were performed using TaqMan Universal PCRMaster Mix (Applied Biosystems) and were performed on a LightCycler 480 (Roche Applied Science). Primers used were the following: CTGAATGCCCAGACAGCTCCAAGC (Vß1), TCA CTGATACGGAGCTGAGGC (Vß2), CCTTGCAGCCTAGAA ATTCAGT (Vß3), GCCTCAAGTCGCTTCCAACCTC (Vß4), 
CATTATGATAAAATGGAGAGAGAT (VB5.1), AAGGTGGAG AGAGACAAAGGATTC (VB5.2), AGAAAGGAAACCTGC CTGGTT (VB5.3), CTCTCACTGTGACATCTGCCC (Vß6), TACAGGGTCTCACGGAAGAAGC (VB7), CATTACTCA TATGTCGCTGAC (VB8.1), CATTATTCATATGGTGCTGGC (VB8.2), TGCTGGCAACCTTCGAATAGGA (VB8.3), TCTCTC TACATTGGCTCTGCAGGC (Vß9), ATCAAGTCTGTAGAG CCGGAGGA (Vß10), GCACTCAACTCTGAAGATCCAGAGC (Vß11), GATGGTGGGGCTTTCAAGGATC (Vß12), AGGCCT AAAGGAACTAACTCCCAC (Vß13), ACGACCAATTCATCC TAAGCAC (V $\beta 14)$, CCCATCAGTCATCCCAACTTATCC (VB15), CACTCTGAAAATCCAACCCAC (Vß16), AGTGTT CCTCGAACTCACAG (V $\beta 17)$, CAGCCGGCCAAACCTAAC ATTCTC (Vß18), CTGCTAAGAAACCATGTACCA (Vß19), TCTGCAGCCTGGGAATCAGAA (Vß20), GCAATCTCTGCT TTTGATGGCTC (C $)$, FAM-AAATGTGACTCCACCCAA GGTCTCCTTGTT-TAMRA (Taqman Probe), All sequences are in the format $5^{\prime} \rightarrow 3^{\prime}$.

\section{Immunoscope Analyses}

PCR were conducted in $50 \mu \mathrm{l}$ cDNA diluted $1 / 50$ with $2 \mathrm{U}$ of Taq polymerase (Promega) in the supplier's buffer. cDNA was amplified using $\mathrm{V} \beta$-specific sense primers and antisense primers hybridizing in $C \beta$ segments or J $\beta 2.3$ (5'TCACAGTGAGCCGGGTGCCTGC-3'). Amplified products were then used as templates for an elongation reaction with fluorescent-tagged oligonucleotides (run-off reactions).

\section{Cloning and Sequencing of TCRBV Rearrangements}

TOPO Blunt cloning kit (Invitrogen Life Technologies) was used. Then, PCR amplification was performed and was followed by a second step of elongation using an ABI PRISM Big DyeTerminator kit (Applied Biosystems). Sequencing products were then read on 16 capillaries (Genetic Analyzer; Applied Biosystems).

\section{Statistical Analysis}

All data are presented as mean \pm standard error of the mean (SEM) and overall differences between variables were evaluated by Mann-Whitney $\mathrm{U}$ test. All tests were performed with GraphPad Prism version 6.0 Software. A $p$-value $\leq 0.05$ was considered significant $\left({ }^{*} p \leq 0.05,{ }^{* *} p \leq 0.01,{ }^{* * *} p \leq 0.005\right)$.

\section{RESULTS}

\section{Vav1 ${ }^{\text {R63W }}$ Confers Increased Susceptibility to Experimental Autoimmune Myasthenia Gravis}

To analyze the impact of $\operatorname{Vav}^{\mathrm{R} 63 \mathrm{~W}}$ on the susceptibility to antibody-mediated EAMG, wild-type and $\mathrm{Vavl}^{\mathrm{R} 63 \mathrm{~W}} \mathrm{KI}$ mice were immunized twice with tAChR at 4 weeks interval (Figure 1A). EAMG was assessed by analyzing the loss of AChR at the NMJ, 3 weeks after the second immunization. AChR contents were significantly reduced in most of the tAChRimmunized mice as compared with mice primed with CFA alone (data not shown). Interestingly, muscle AChR loss was

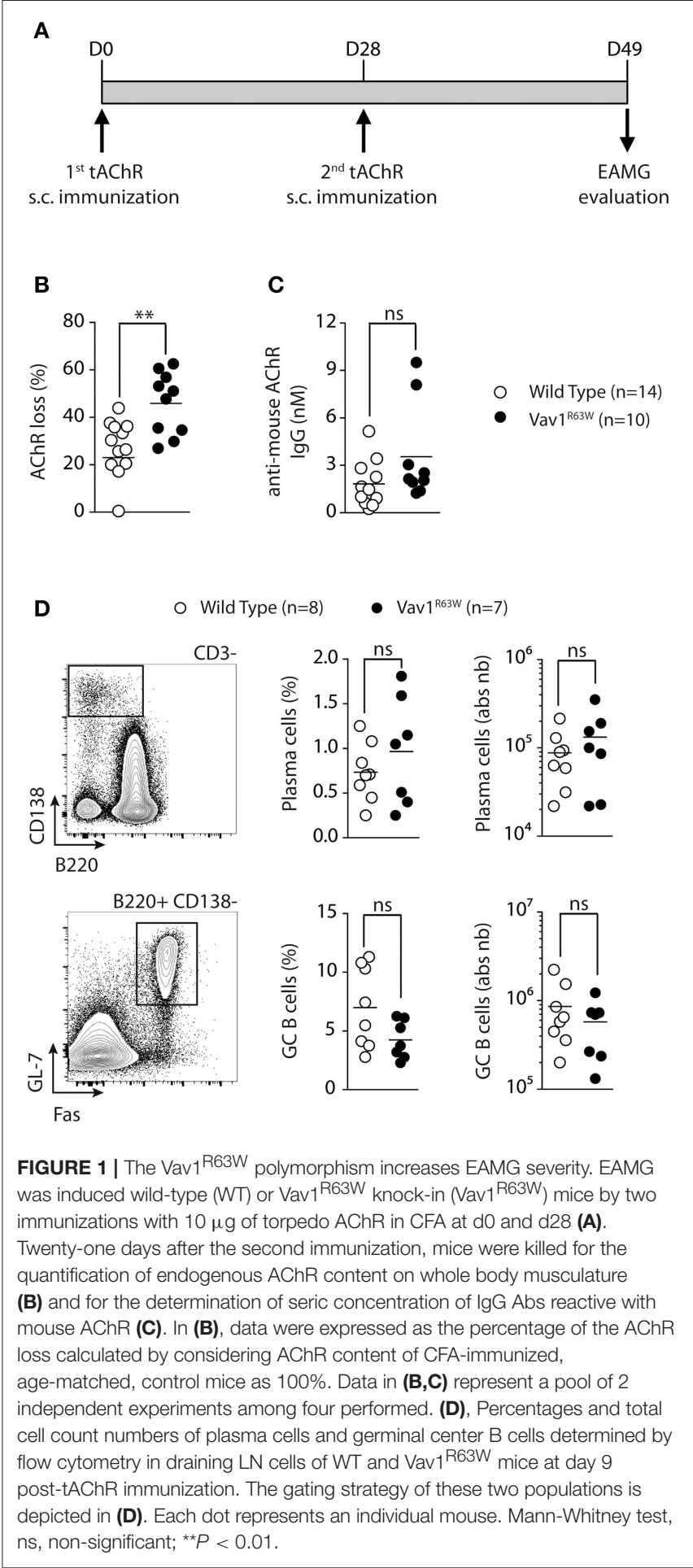

significantly more pronounced in Vav1 ${ }^{\mathrm{R} 63 \mathrm{~W}} \mathrm{KI}$ mice as compared to wild-type mice (Figure 1B). Next, we determined the effect of $\mathrm{Vavl}^{\mathrm{R} 63 \mathrm{~W}}$ on the production of AChR-specific autoantibodies (Figure 1C). Vav1 ${ }^{\mathrm{R} 63 \mathrm{~W}}$ KI mice exhibited a non-significant increase in the concentration of autoantibodies ( 3.24 vs. $2.33 \mathrm{nM}$ in wild-type littermates). This is consistent with previous studies showing that the serum concentration of AChR-specific 
antibodies does not necessarily correlate with AChR loss in total body musculature $(30,31)$. Of note, the percentage and absolute numbers of plasma cells and germinal center B cells were similar between WT and Vav1 ${ }^{\mathrm{R} 63 \mathrm{~W}}$ KI Mice (Figure 1D). Together, these data show that Vav1 ${ }^{\mathrm{R} 63 \mathrm{~W}}$ favors the development of EAMG and this was not associated with the disruption of $\mathrm{B}$ cell response.

\section{Vav1 ${ }^{\mathrm{R} 63 \mathrm{~W}}$ Favors the Production of Effector Cytokines by tAChR-Specific CD4 ${ }^{+}$T Cells}

Next, we evaluated the impact of $\mathrm{Vav1}^{\mathrm{R} 63 \mathrm{~W}}$ on tAChR-specific $\mathrm{CD}^{+}{ }^{+} \mathrm{T}$ cell responses. In C57BL6 mice, tAChR-specific CD ${ }^{+}$ $\mathrm{T}$ cells are mostly directed against the immunodominant epitope of the protein contained in the sequence 146-162 of the tAChR $\alpha$-subunit presented by I-A ${ }^{\mathrm{b}}$ molecules. As shown in Figures 2A,B, the proliferative responses of $\mathrm{CD}^{+} \mathrm{T}$ cells specific for tAChR or its immunodominant epitope a146162 were similar between $\mathrm{Vav1}^{\mathrm{R} 63 \mathrm{~W}} \mathrm{KI}$ mice and littermate controls. In contrast, Vav1 ${ }^{\mathrm{R} 63 \mathrm{~W}} \mathrm{CD}^{+}{ }^{+} \mathrm{T}$ cells produced higher levels of IFN- $\gamma$, IL-17A, GM-CSF, and IL-13 in response to tAChR (Figure 2A) or its immunodominant epitope $\alpha 146-$ 162 (Figure 2B). We also analyzed the cytokine expression by $\mathrm{CD}^{+} \mathrm{T}$ cells upon stimulation with the immunodominant epitope $\alpha 146-162$ using intracytoplasmic staining. The frequency of $\mathrm{CD}^{+} \mathrm{T}$ cells expressing IFN- $\gamma$, GM-CSF, or IL-17A was significantly increased in $\operatorname{Vav} 1^{\mathrm{R} 63 \mathrm{~W}} \mathrm{KI}$ mice as compared to wild-type controls (Figure 3A). In contrast, there were no differences between the mean fluorescence intensity (MFI) of cytokine expression between groups (Figure 3B) suggesting that the observed increased production of inflammatory cytokines by $\mathrm{Vav1}^{\mathrm{R} 63 \mathrm{~W}} \mathrm{KI} \mathrm{CD} 4^{+} \mathrm{T}$ cells is the consequence of an increased frequency of $\mathrm{CD}^{+} \mathrm{T}$ cells producing a given cytokine, rather than an increased cytokine production per cell. Similar results were obtained when $\mathrm{CD} 4^{+} \mathrm{T}$ cells were purified from mice that had been immunized with the $\alpha 146-162$ immunodominant epitope (Figure 4). Thus, these results suggest that the Vav1 ${ }^{\mathrm{R} 63 \mathrm{~W}}$ variant favors the development of EAMG by increasing the frequency of AChR-specific effector $\mathrm{CD} 4^{+} \mathrm{T}$ cells.

\section{Vav1 ${ }^{\mathrm{R} 63 \mathrm{~W}}$ Impacts on the Frequency of 146-162 AChR-Specific CD4 ${ }^{+}$T Cells}

To address whether the Vav1 ${ }^{\mathrm{R} 63 \mathrm{~W}}$ variant might indeed impact the AChR-responsive $\mathrm{CD} 4^{+} \mathrm{T}$ cell compartment, we examined I$\mathrm{A}^{\mathrm{b}}$ restricted $\mathrm{T}$ cell responses to the immuno-dominant peptide $\alpha 146-162$ of AChR in wild-type and Vav1 ${ }^{\mathrm{R} 63 \mathrm{~W}}$ littermates. We tracked the $\alpha 146-162$ AChR-specific $\mathrm{CD}^{+}{ }^{+} \mathrm{T}$ cells using the corresponding pMHCII tetramer in the draining LN (dLN) after subcutaneous (sc) immunization with purified tAChR in CFA. At day 9, which corresponds to the peak of the effector response, we selectively focused on $\mathrm{CD}^{+}$cells by
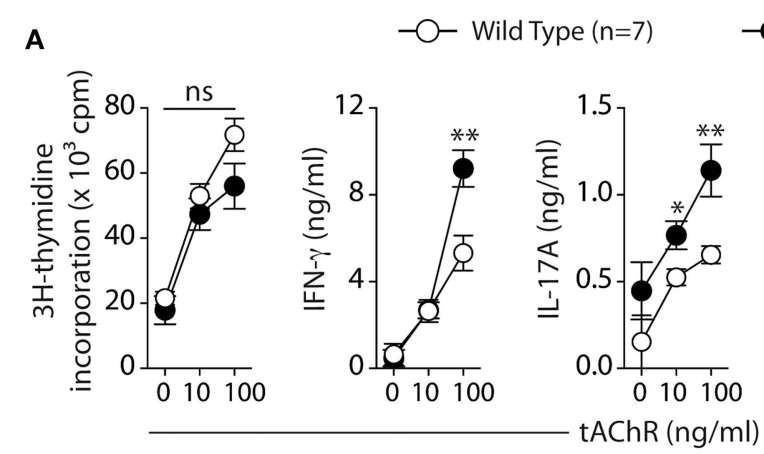

$\operatorname{Vav1}^{\mathrm{R63W}}(\mathrm{n}=10)$
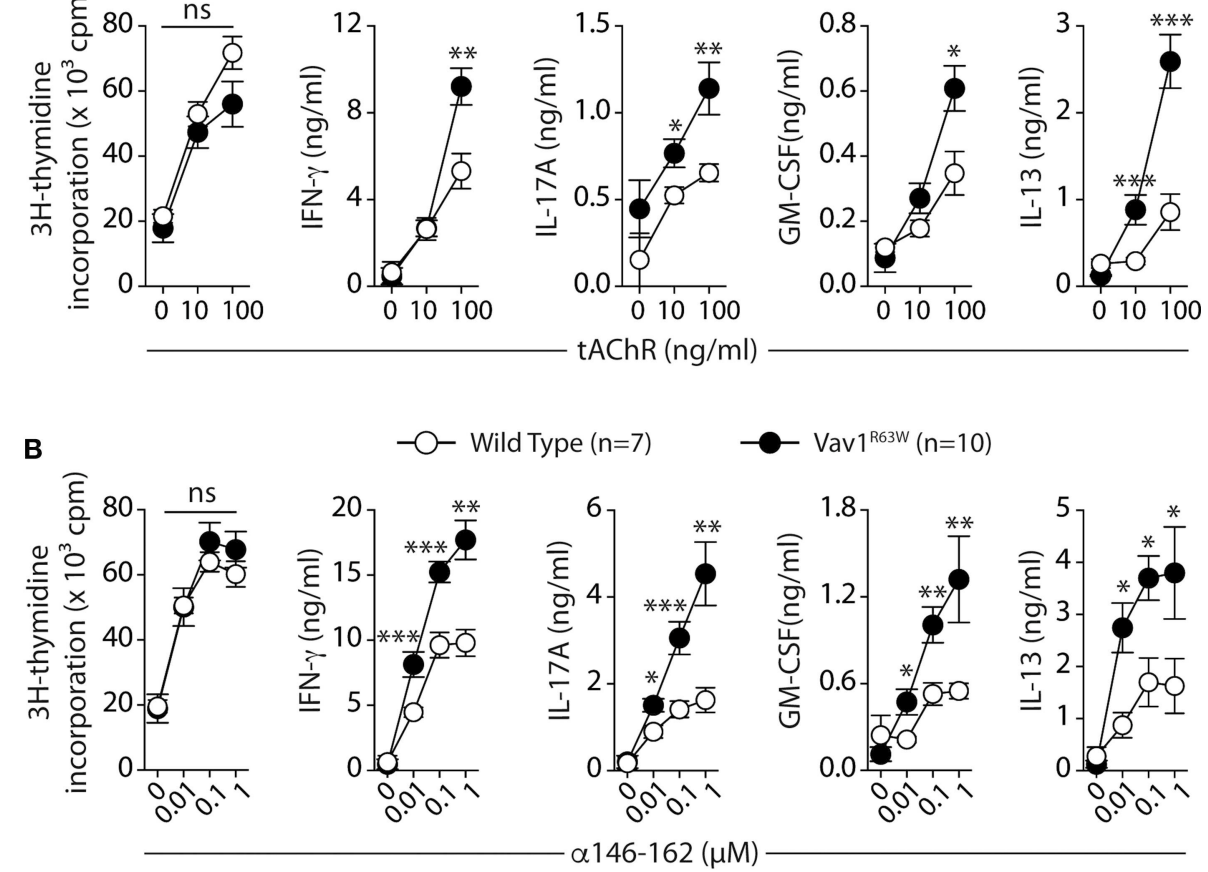

FIGURE 2 | Production of cytokines after tAChR immunization of WT and Vav1 ${ }^{\text {R63W }}$ mice. WT or Vav1 ${ }^{R 63 W}$ mice were immunized with $10 \mu \mathrm{g}$ of tAChR in CFA. Draining LNC were harvested 9 days later and stimulated for $48 \mathrm{~h}$ with variable concentrations of tAChR (A) or with the $\alpha 146-162$ immunodominant AChR peptide (B) Cytokine secretion was quantified by ELISA and CBA kit in the supernatants. Data represent a pool of 2 independent experiments. Mann-Whitney test, ns, non-significant; ${ }^{*} P<0.05 ;{ }^{\star \star} P<0.01 ;{ }^{\star \star *} P<0.005$. 
A

\section{$\mathrm{TCR}+$ cells}
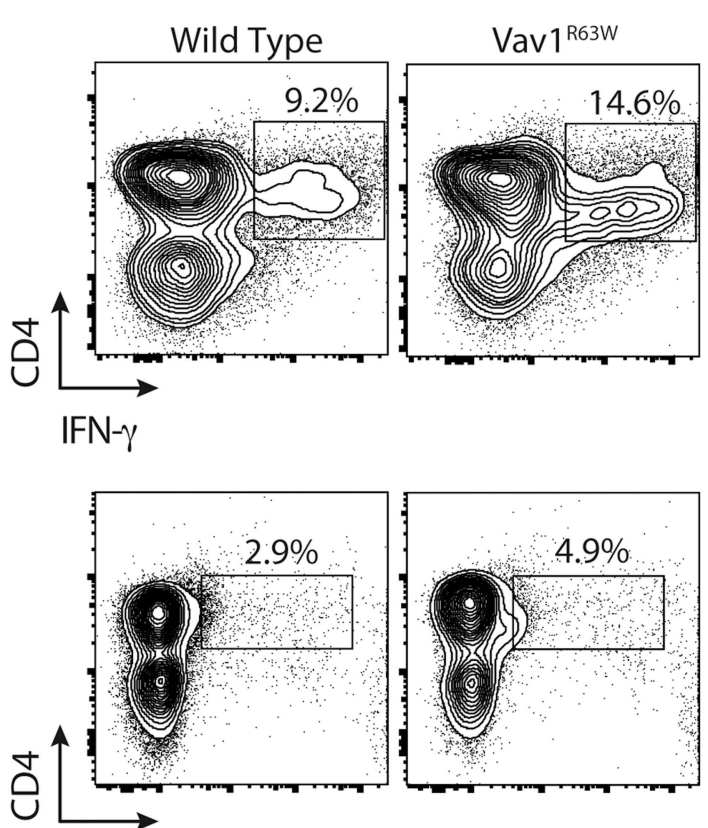

IL-17A

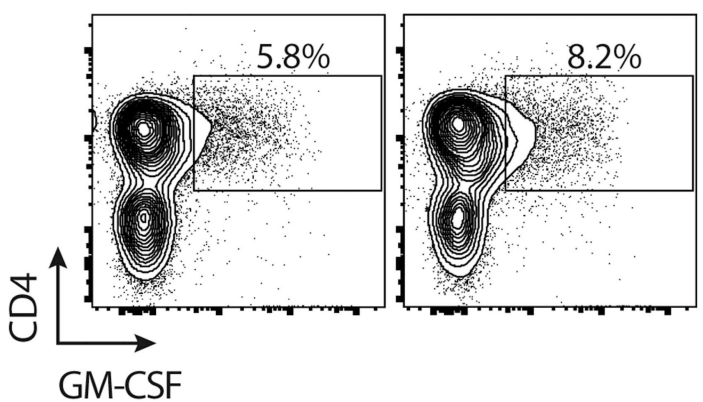

B

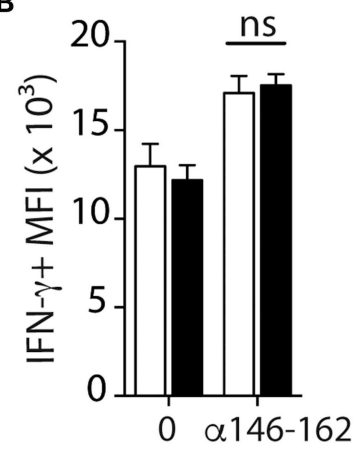

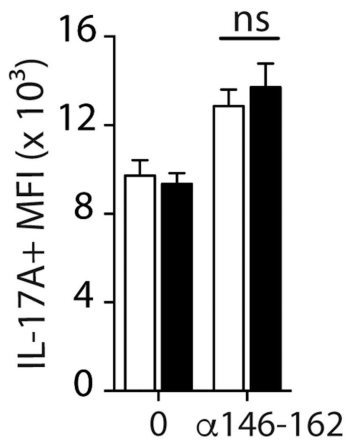

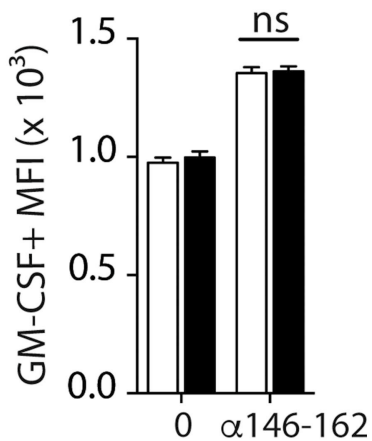

Wild Type $(n=7)$
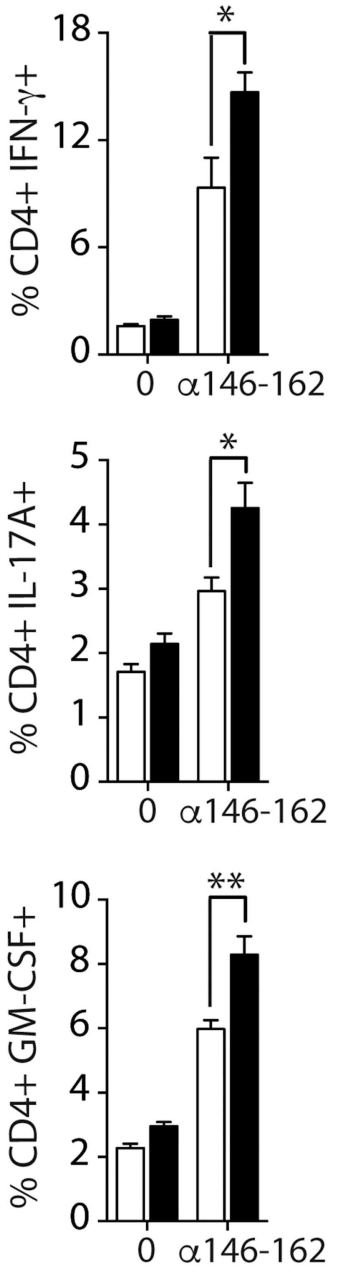
A

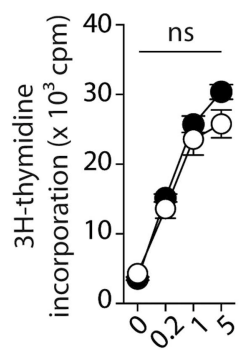

$-\bigcirc-$ Wild Type $(n=5)$

$-\operatorname{Vav}^{\mathrm{R} 63 \mathrm{~W}}(\mathrm{n}=8)$
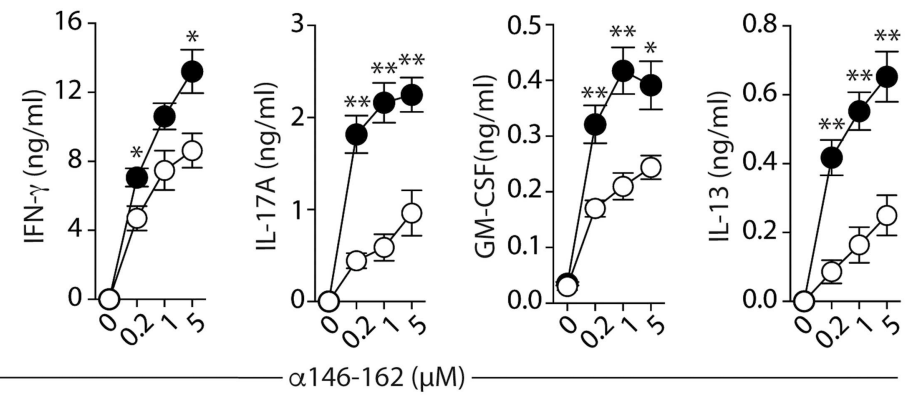

- $146-162(\mu \mathrm{M})$

B
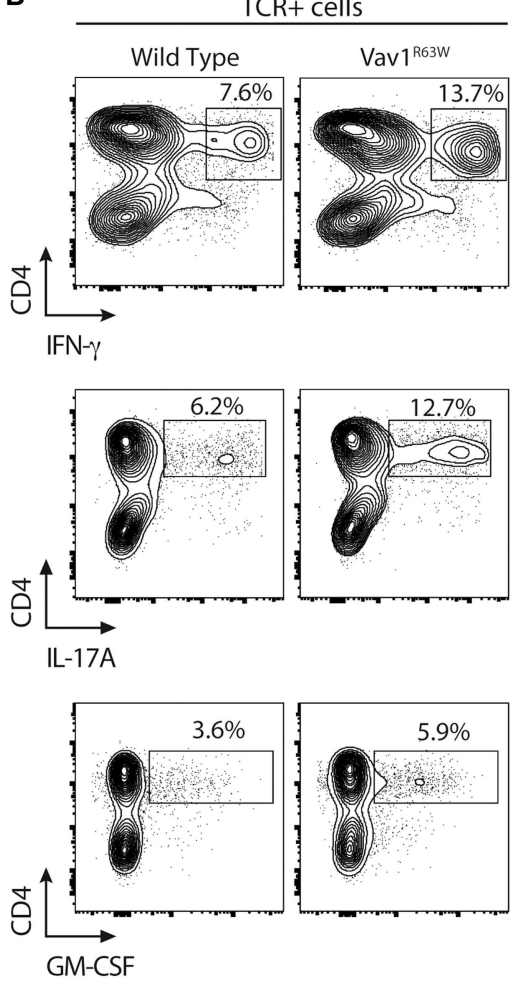
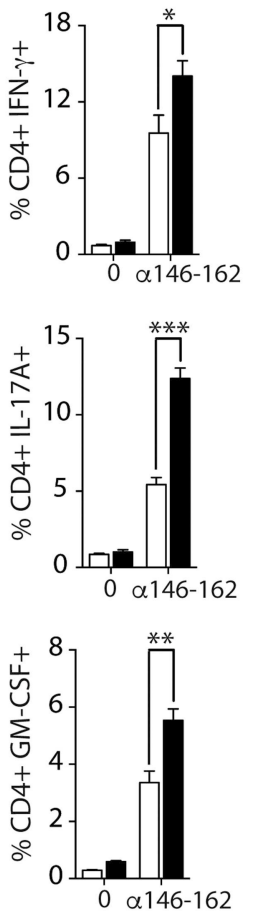

Wild Type $(n=5)$
C
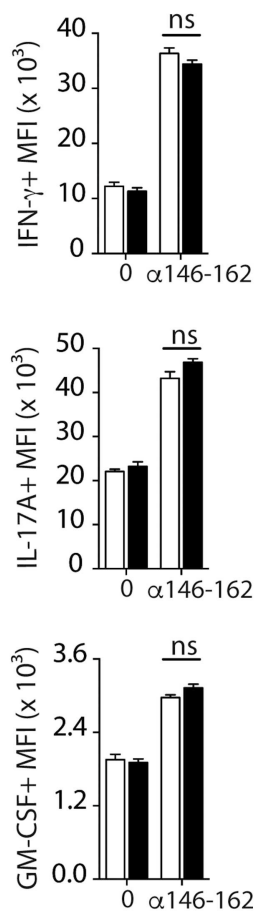

$\operatorname{Vav} 1^{\text {R63W }}(n=8)$

FIGURE 4 | Cytokine production and frequency of CD4 T cell-producing cytokines after $\alpha 146-162$ AChR peptide immunization of WT and Vav1 R63W mice. WT or Vav1 ${ }^{R 63 W}$ mice were immunized with $50 \mu \mathrm{g}$ of $\alpha 146-162$ AChR peptide. Draining LN cells were harvested 9 days later and stimulated for $48 \mathrm{~h}$ with increasing concentrations of $\alpha$ 146-162 AChR peptide. Cytokine secretion was quantified by ELISA and CBA kit in the supernatants (A). The frequency of TCR + CD4 ${ }^{+}$LN cells producing cytokines was determined by intracytoplasmic staining after $72 \mathrm{~h}$ stimulation without or with $\alpha 146$ - $162 \mathrm{AChR}$ peptide (1 $\mu \mathrm{M})$ (B). The intensity of expression of each cytokine by TCR ${ }^{+} \mathrm{CD} 4^{+} \mathrm{LN}$ cells was quantified by the Mean Fluorescence Intensity (MFI) (C). Data represent a pool of 2 independent experiments.

Mann-Whitney test, ns, non-significant; ${ }^{\star} P<0.05 ;{ }^{* \star} P<0.01 ;{ }^{* \star \star} P<0.005$.

gating out $\mathrm{CD} 8 \alpha^{+}$and $\mathrm{B} 220^{+}$cells (Figure 5A). Almost no pMHCII tetramer-positive cells were detected in wild-type and $\mathrm{Vav1}^{\mathrm{R} 63 \mathrm{~W}}$ mice immunized with CFA alone (PBS in CFA, Figure 5B). In contrast, we detected $\mathrm{CD}_{4}{ }^{+}$pMHCII tetramer ${ }^{+} \alpha 146-162$ AChR-specific $\mathrm{CD}^{+}{ }^{+} \mathrm{T}$ cells in the $\mathrm{dLN}$ after immunization of wild-type and $\mathrm{Vav1}{ }^{\mathrm{R} 63 \mathrm{~W}} \mathrm{KI}$ mice with tAChR in CFA (Figure 5B). In accordance with the cytokine data, the frequency of CD44 ${ }^{+}$pMHCII tetramer ${ }^{+} \alpha 146-162$ AChRspecific $\mathrm{CD}^{+}{ }^{+} \mathrm{T}$ cells was significantly higher in Vav1 ${ }^{\mathrm{R} 63 \mathrm{~W}} \mathrm{KI}$ mice as compared to littermate controls. Together, these results demonstrate that the higher cytokine production observed in Vav1 ${ }^{\mathrm{R} 63 \mathrm{~W}} \mathrm{KI}$ mice in response to the immunizing antigen is associated with an increased frequency of antigen-specific $\mathrm{CD} 4^{+}$ $\mathrm{T}$ cells recognizing the $\alpha 146-162$ immunodominant peptide of AChR.

Since the Vav1 ${ }^{\mathrm{R} 63 \mathrm{~W}}$ mutation impacts thymic development of Treg $(26,27)$, we investigated if this mutation alters Treg AChR-reactive $\mathrm{T}$ cells after tAChR immunization. For this 

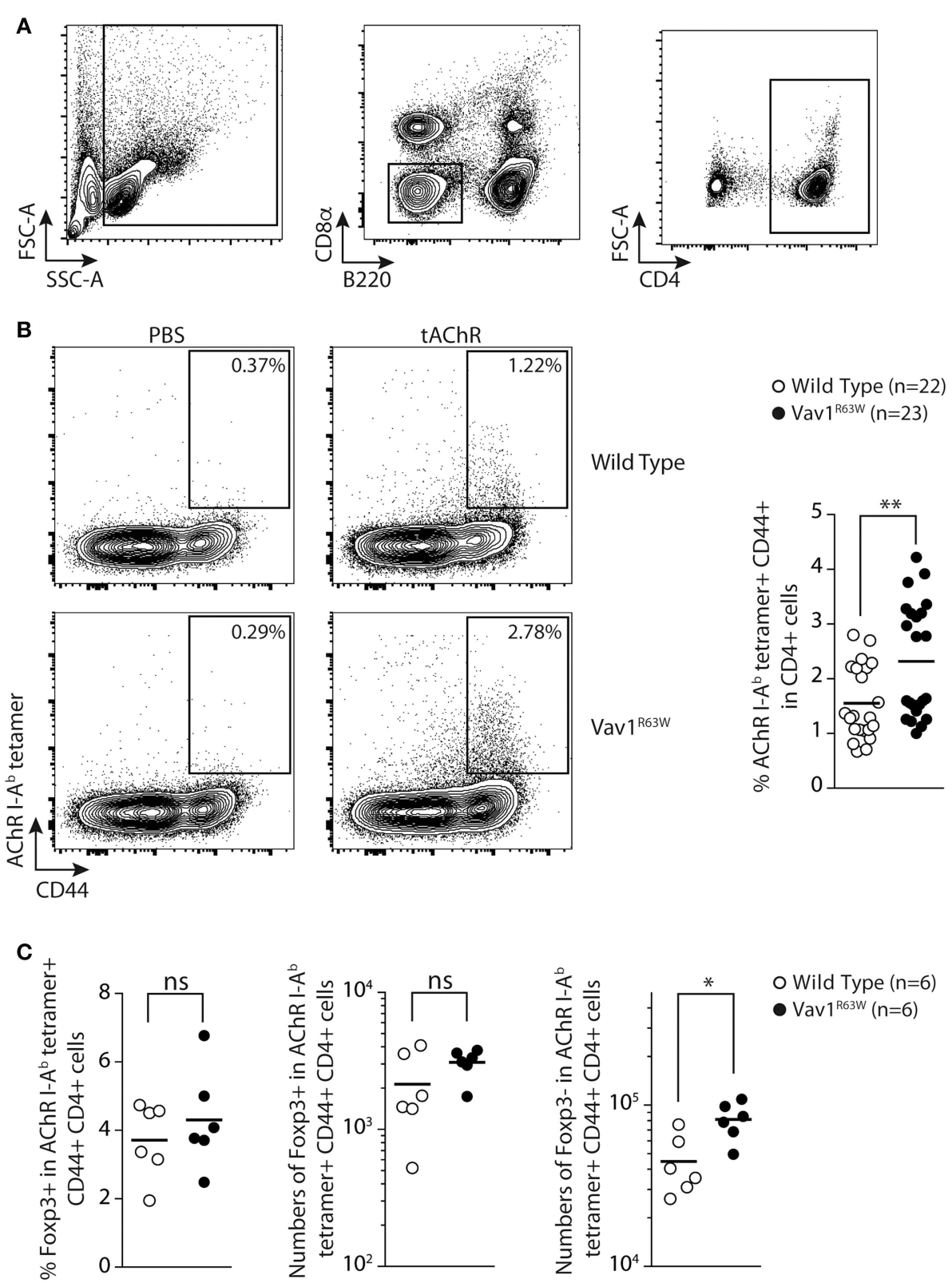

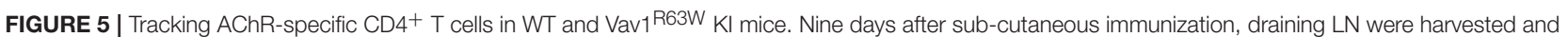
analyzed by flow cytometry. The gating strategy of total CD4 ${ }^{+} \mathrm{T}$ cells is depicted in (A) by excluding B220 ${ }^{+}$and $\mathrm{CD} \boldsymbol{\alpha}^{+}$cells and by positively selecting CD4 ${ }^{+}$cells. The detection of tAChR-specific activated $\mathrm{CD} 4^{+} \mathrm{T}$ cells (AChR I-A $\mathrm{A}^{\mathrm{b}}$ tetramer ${ }^{+} \mathrm{CD} 44^{+}$) are depicted for wild-type and Vav ${ }^{\mathrm{R} 63 \mathrm{~W}} \mathrm{KI}$ mice after immunization with $\mathrm{PBS}$ in CFA or tAChR in CFA (B) $\left(n=22\right.$ for wild-type mice and $n=23$ for Vav1 ${ }^{R 63 W} \mathrm{KI}$ mice). Data represent a pool of 4 independent experiments. Intracellular expression of Foxp3 was assessed in tAChR-specific CD4 ${ }^{+}$T cells. Frequency of Foxp3 ${ }^{+}$Treg and absolute numbers of Foxp3 ${ }^{+}$Treg and Foxp3- effector tAChR-specific CD4 ${ }^{+}$T cells are depicted $\mathbf{( C )}\left(n=6\right.$ for wild-type mice and $n=6$ for Vav1 ${ }^{R 63 W} \mathrm{KI}$ mice). Each dot represents an individual mouse; horizontal lines denote the mean value of groups. Mann-Whitney test, ${ }^{\star} P<0.05,{ }^{\star \star} P<0.01$.

purpose, we analyzed the frequency and absolute numbers of $\alpha 146-162$ AChR-specific $\mathrm{CD}^{+} \mathrm{T}$ cells that were Foxp3 ${ }^{+}$ corresponding to AChR-antigen specific regulatory $\mathrm{T}$ cells and Foxp3- corresponding to effector $\mathrm{T}$ cells (Figure 5C). Surprisingly, the frequency and absolute numbers of $\alpha 146-162$ AChR-specific $\mathrm{CD}^{+}{ }^{+}$Treg were similar between Vav1 ${ }^{\mathrm{R} 63 \mathrm{~W}} \mathrm{KI}$ CD4 T cells and littermate control mice. However, the absolute number of Foxp3- effector AChR-specific CD4 ${ }^{+} \mathrm{T}$ cells was significantly higher in $\mathrm{Vav1}^{\mathrm{R} 63 \mathrm{~W}}$ as compared to WT mice (Figure 5C). Together, these results demonstrate that the highest cytokine production observed in $\mathrm{Vav1}^{\mathrm{R} 63 \mathrm{~W}} \mathrm{KI}$ mice in response to the immunizing antigen is associated with an increased frequency of antigen specific effector CD4 T cells recognizing the immunodominant peptide $\alpha 146-162$ of AChR as revealed by 

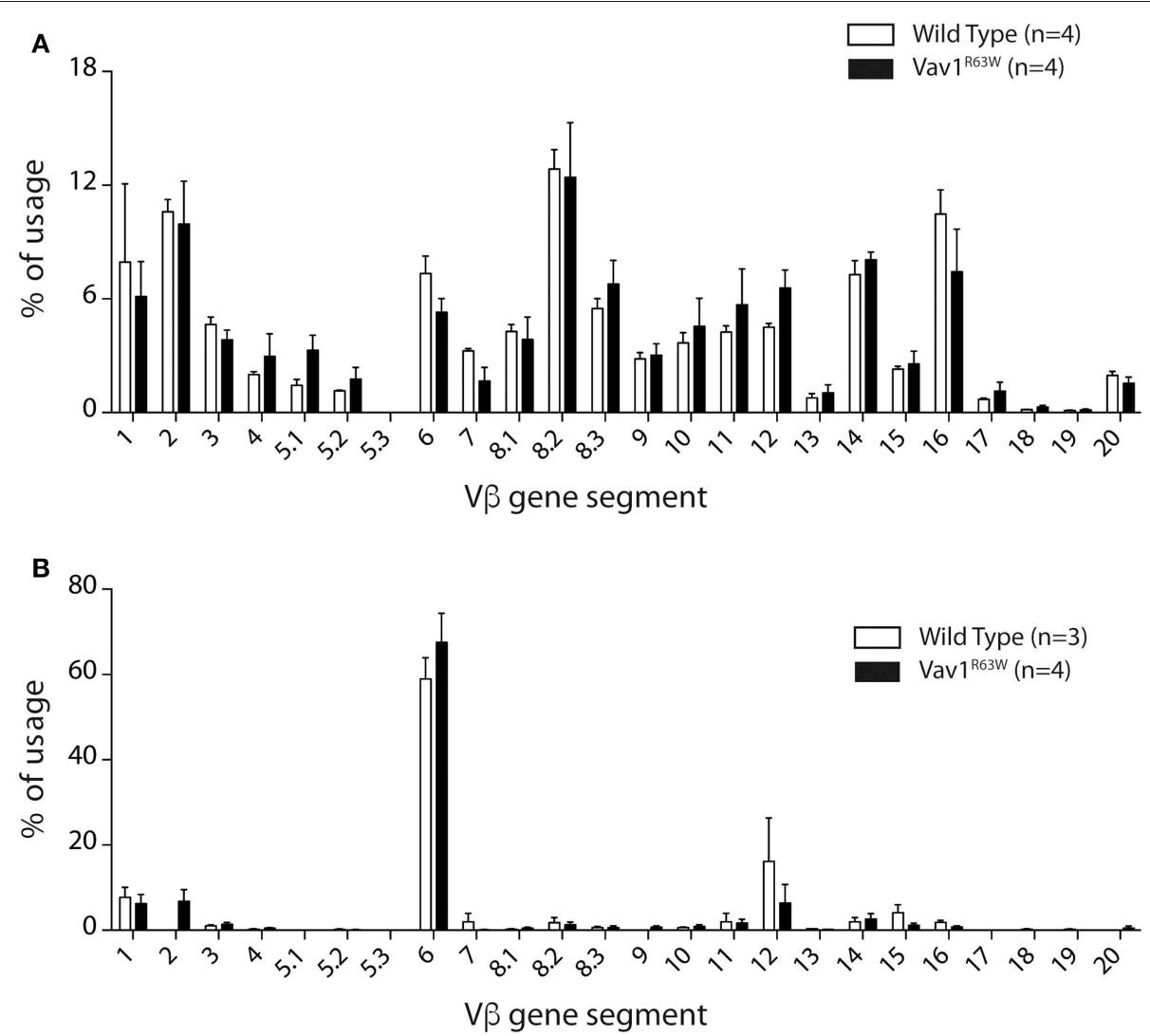

C

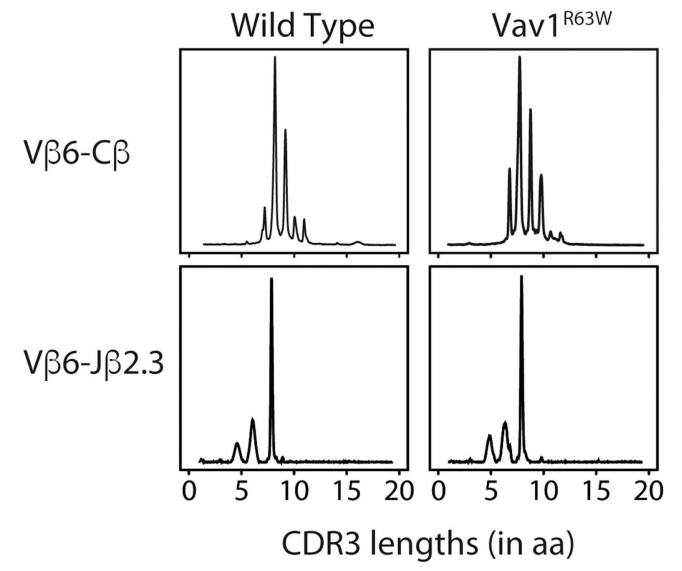

FIGURE 6 | VB gene segment usage and CDR3 size distribution of $\alpha 146-162$ AChR-specific CD4 ${ }^{+}$T cells from WT and Vav1 ${ }^{\text {R63W }}$ mice. Nine days after sub-cutaneous immunization, draining LN were harvested and tAChR-specific activated CD4 ${ }^{+}$T cells $\left(A C h R I-A^{b}\right.$ tetramer ${ }^{+}$CD44 $\left.{ }^{+}\right)$were FACS sorted out prior to RNA isolation and RT-coupled real time PCR analysis. Alternatively, lymph node CD4 ${ }^{+} \mathrm{T}$ cells were isolated from naive mice. V $\beta$ gene usage for naive (A) and tAChR-specific CD4 ${ }^{+}$T cells (B) isolated from WT (white) or Vav1 ${ }^{\text {R63W }}$ (black) mice are depicted. CDR3b size distributions from one representative sample of each background are presented (C). Rearrangements shown are VB6-CB and VB6-J $\alpha 2.3$.

tetramer labeling but not Treg Foxp3 ${ }^{+}$AChR-specific CD4 ${ }^{+} \mathrm{T}$ cells. Thus, this imbalance between the AChR reactive effector and Treg cells could contribute to the increased susceptibility of Vav1 ${ }^{\text {R63W }}$ KI mice to EAMG.

\section{Vav1 ${ }^{\mathrm{R} 63 \mathrm{~W}}$ Influences the TCR Repertoire of AChR-Responsive CD4 ${ }^{+}$T Cells}

To analyze if the higher frequency of AChR-specific $\mathrm{CD} 4^{+}$ $\mathrm{T}$ cells in Vav1 ${ }^{\mathrm{R} 63 \mathrm{~W}} \mathrm{KI}$ mice could be the consequence of a 
modification of the TCR repertoire, we first examined whether the $\mathrm{Vav1}^{\mathrm{R} 63 \mathrm{~W}}$ alters the V $\beta$ chain usage of $\alpha 146-162$ AChRspecific CD4 ${ }^{+} \mathrm{T}$ cells. For this aim, we FACS-sorted $\alpha 146-162$ AChR specific $\mathrm{CD}^{+}{ }^{+} \mathrm{T}$ cells from tAChR-primed mice using the staining strategy presented in Figure 5. Expression of the different V $\beta$ gene segments was then analyzed by real-time PCR. Parallel studies showed that the $\mathrm{V} \beta$ usage of naive $\mathrm{CD}^{+} \mathrm{T}$ cells from unprimed wild-type and Vav1 ${ }^{\mathrm{R} 63 \mathrm{~W}} \mathrm{KI}$ mice were similar (Figure 6A). In the $\alpha 146-162$ AChR-specific CD $4^{+} \mathrm{T}$ cells from wild-type and Vav1 ${ }^{\mathrm{R} 63 \mathrm{~W}} \mathrm{KI}$ mice, we observed a marked amplification of the V $\beta 6$ segment, representing around $60 \%$ of the total $\mathrm{V} \beta$ gene usage irrespective of the genetic background (Figure 6B). V $\beta 1, V \beta 2, V \beta 12$, and $V \beta 14$ gene segments were also detected, although at lower frequencies, in AChR-responsive $\mathrm{CD}^{+} \mathrm{T}$ cells from all mice analyzed. Since only V $\beta 6$ values were significantly higher when compared to $\mathrm{CD} 4^{+} \mathrm{T}$ cells from naive mice, this indicates that $\alpha 146-162$ AChR-specific CD4 ${ }^{+} \mathrm{T}$ cells preferentially use this $\mathrm{V} \beta$ gene segment, both in wild-type and $\mathrm{Vav1}^{\mathrm{R} 63 \mathrm{~W}}$ KI mice.

To further examine the impact of $\mathrm{Vav1}^{\mathrm{R} 63 \mathrm{~W}}$ on the AChRspecific $\mathrm{CD}^{+}{ }^{+} \mathrm{T}$ cell repertoire, we analyzed the CDR3 $\beta$ length distribution of the V $\beta 6$ chains used by purified AChR-responsive $\mathrm{CD}^{+} \mathrm{T}$ cells. Run-off reactions were made with $12 \mathrm{~J} \beta$-specific primers on the V $\beta 6-C \beta$ PCR products. We observed that $\alpha 146-$ 162 AChR-specific CD4 ${ }^{+} \mathrm{T}$ cells preferentially used the V $\beta 6$ $\mathrm{J} \beta 2.3$ rearrangement, with a single peak corresponding to clonal expansion with a CDR3 of eight amino acids (Figure 6C). This rearrangement was found in all mice tested. We then used RT-PCR to amplify the V $\beta 6-J \beta 2.3$ region of these chains and sequenced the products after cloning (Table $\mathbf{1}$ ). The analysis of around 150 clones derived from three pools of wild-type and Vav1 ${ }^{\mathrm{R} 63 \mathrm{~W}}$ mice identified 39 distinct CDR3 sequences. In wild-type mice, the dominant and public repertoire of $\alpha 146$ 162 AChR-specific $\mathrm{CD}^{+}{ }^{+} \mathrm{T}$ cells contained the CDR3 amino acid sequence SIRGAETL. Interestingly, we detected 6 different nucleotide sequences all encoding this same CDR3, suggestive of the existence of a selective pressure to use this CDR3. In Vav1 ${ }^{\mathrm{R} 63 \mathrm{~W}}$ KI mice, the CDR3 SIRGAETL sequence was also public, since it was found in the 3 different pools. Strikingly, two other CDR3 were found to be public in Vav1 ${ }^{\mathrm{R} 63 \mathrm{~W}} \mathrm{KI}$ mice. Indeed, SIESAETL and SIEGTETL were found in all Vav1 ${ }^{\mathrm{R} 63 \mathrm{~W}}$ samples. In contrast, SIESAETL was only found in 2 out of 3 wild-type samples and SIEGTETL in none of them. Altogether, our data indicate that the highest EAMG severity and cytokine response of $\mathrm{CD}^{+}{ }^{+} \mathrm{T}$ cells from Vav1 ${ }^{\mathrm{R} 63 \mathrm{~W}} \mathrm{KI}$ mice after tAChR challenge is associated with a different TCR repertoire of $\mathrm{CD} 4^{+}$ $\mathrm{T}$ cells elicited in that response.

\section{DISCUSSION}

In the present study, we analyzed the impact of the recently identified natural $\operatorname{Vav1}^{\mathrm{R} 63 \mathrm{~W}}$ variant on the susceptibility to EAMG, a T cell-dependent, antibody-mediated autoimmune disease. We found that the $\mathrm{Vav1}^{\mathrm{R} 63 \mathrm{~W}} \mathrm{KI}$ mice were more susceptible to EAMG and that this was associated with an increased production of inflammatory effector cytokines (IFN$\gamma$, IL-17A, and GM-CSF) by autoreactive $\mathrm{CD}^{+} \mathrm{T}$ cells and the emergence of a different TCR repertoire of $\mathrm{CD}^{+}$
$\mathrm{T}$ cells engaged in response to AChR. Since our previous studies show that Vav1 ${ }^{\mathrm{R} 63 \mathrm{~W}}$ displays normal GEF activity but reduced adaptor functions, this study establishes that Vav1 adaptor functions influence susceptibility to EAMG by impacting the TCR repertoire of AChR-specific autoreactive $\mathrm{CD} 4^{+}$ T cells.

Excessive activation and/or altered differentiation of specific $\mathrm{CD}^{+}{ }^{+} \mathrm{T}$ cell subsets may lead to the development of variable immune-based disorders, depending on the type of $\mathrm{CD}^{+} \mathrm{T}$ cell population involved. Excessive Th1 and Th17 responses have been shown to be involved in the development of MG and EAMG (32-37). Consistent with these findings, we observed that the enhanced susceptibility of Vav1 ${ }^{\mathrm{R} 63 \mathrm{~W}}$ KI mice to EAMG was associated with an increased frequency of autoreactive $\mathrm{CD} 4^{+} \mathrm{T}$ cells producing Th1 and Th17 cytokines. These results, however, contrast with our previous study showing that $\mathrm{Vav1}^{\mathrm{R} 63 \mathrm{~W}} \mathrm{KI}$ $\mathrm{CD}^{+} \mathrm{T}$ cells specific for the myelin protein MOG produce less Th1 and Th17 cytokines upon immunization with $\mathrm{MOG}_{35-55}$. This may suggest that the effect of $\mathrm{Vav1}^{\mathrm{R} 63 \mathrm{~W}}$ on $\mathrm{CD}^{+} \mathrm{T}$ cell polarization depends on the autoantigen used for immunization. These data also suggest that the effect of Vav1 ${ }^{\mathrm{R} 63 \mathrm{~W}}$ on cytokine production by $\mathrm{CD}^{+} \mathrm{T}$ cells is intrinsic to $\mathrm{T}$ cells and is therefore probably linked to the strength of TCR-dependent signaling pathways upon antigen recognition (38). Indeed, the differentiation of $\mathrm{CD}^{+}{ }^{+} \mathrm{T}$ cells into different effector subsets depends on signaling pathways triggered by the TCR, which may vary qualitatively and quantitatively with time according to the expression level of antigenic ligands at the surface of APCs and to the affinity of antigenic pMHC for TCRs (39, 40). In general, weak TCR signaling favors Th2 differentiation, whereas stronger TCR signaling favors Th1/Th17 differentiation $(38,41,42)$. Since AChR is highly immunogenic when compared to MOG, our data suggest that engagement of the TCR of AChR-specific $\mathrm{CD}^{+} \mathrm{T}$ cells induces a strong TCR signaling responsible for their differentiation into Th1 and Th17. Of note, we did also observe an increased production of IL-13, a Th2 cytokine, suggesting that other mechanisms could be involved.

The strength of the signal originating from the TCRs upon interaction with self-peptide/MHC ligands expressed on thymic stromal cells plays a key role of the fate of developing $\mathrm{T}$ cells $(38,39,43)$. Thymocytes are either subjected to apoptosis for very low self-reactivity, or positively selected for low self-reactivity and negatively selected for high self-reactivity. Some thymocytes with high self-reactivity could differentiate into Foxp3-expressing regulatory $\mathrm{T}$ cell lineage. Therefore, the alteration of TCR signaling in developing $\mathrm{T}$ cells might change the sensitivity of self-reactive $\mathrm{T}$ cells to thymic selection and susceptibility to autoimmunity. Studies of $\mathrm{Vav1}^{\mathrm{R} 63 \mathrm{~W}}$ mice reveal that Vav1 ${ }^{\mathrm{R} 63 \mathrm{~W}}$ causes a defect in TCR-driven thymic selections (26). Based on the data concerning the TCR repertoire of AChR reactive $\mathrm{T}$ cells, we hypothesize that $\mathrm{Vav1}^{\mathrm{R} 63 \mathrm{~W}}$ might influence the susceptibility to EAMG by impacting on the thymic selection of AChR-specific $\mathrm{CD}^{+}{ }^{+} \mathrm{T}$ cells. We think that the reduced TCR signaling resulting from the adaptor function defect in Vav1 ${ }^{\mathrm{R} 63 \mathrm{~W}}$ mice $(26,27)$ lowered the threshold of thymic negative selection, thereby permitting the escape of high-affinity AChR-specific clones that would normally be 
TABLE 1 | CDR3 $\beta$ sequences of $\alpha 146-162$ AchR specific CD4+ T cells (VB6-J $\beta 2.3$ rearrangement) ${ }^{a}$.

\begin{tabular}{|c|c|c|c|c|c|c|}
\hline Background & $3^{\prime} \mathrm{V} \beta$ end & N/P/D $\beta$ & $5^{\prime} \mathrm{J} \beta$ beggining & Deduced aa CDR3 & & Frequency $(\%)^{b}$ \\
\hline \multirow[t]{7}{*}{ WT\#1 } & agtata & aggg & gtgcagaaacgctg & SIRGAETL & & 9 \\
\hline & agtatag & ag & agtgcagaaacgctg & $\underline{\text { SIESAETL }}$ & 35 & \\
\hline & agtatag & aа & agtgcagaaacgctg & & 4 & 48 \\
\hline & agtat & tgag & agtgcagaaacgctg & & 9 & \\
\hline & agtatag & agaca & gcagaaacgctg & SIETAETL & & 17 \\
\hline & agtatag & aaacaa & cagaaacgctg & SIETTETL & & 13 \\
\hline & agt & caagagggt & gaaacgctg & SQEGETL & & 4 \\
\hline \multirow[t]{8}{*}{ WT\#2 } & agtata & aggggg & gcagaaacg & SIRGAETL & 8 & 28 \\
\hline & agtata & aggg & gtgcagaaacgctg & & 8 & \\
\hline & agtat & ccgcg & gtgcagaaacgctg & & 8 & \\
\hline & agta & gtggggag & gaaacgctg & SSGEETL & & 15 \\
\hline & agtat & cgaggggtcagag & acgctg & SIEGSETL & & 4 \\
\hline & agtatag & ggga & agaaacgctg & SIGEETL & & 4 \\
\hline & agtatag & agat & agaaacgctg & SIEIETL & & 4 \\
\hline & agtata & caa & agtgcagaaacgctg & SIQSAETL & 4 & \\
\hline \multirow[t]{5}{*}{ WT\#3 } & agtat & ccggggg & gcagaaacgct & $\underline{\text { SIRGAETL }}$ & 20 & 28 \\
\hline & agtat & caggg & gtgcagaaacgctg & & 8 & \\
\hline & agtatag & aggggt & cagaaacgctg & SIEGSETL & & 40 \\
\hline & agtata & aggggcgg & agaaacgctg & SIRGGETL & & 20 \\
\hline & agtat & ccaggag & gcagaaacgctg & SIQEAETL & & 4 \\
\hline \multirow{2}{*}{$\operatorname{Vav1}{ }^{R 63 W_{\# 1}}$} & agtatag & aa & agtgcagaaacgctg & & 9 & \\
\hline & agtatag & agggaacg & gaaacgctg & SIEGTETL & & 32 \\
\hline \multirow[t]{6}{*}{$\operatorname{Vav1}{ }^{R 63 W_{\# 2}}$} & agtat & ccgggga & gcagaaacgctg & SIRGAETL & & 4 \\
\hline & agtat & tgaa & agtgcagaaacgctg & SIESAETL & 33 & 46 \\
\hline & agtatag & aа & agtgcagaaacgctg & & 13 & \\
\hline & agtatag & agggaa & cagaaacgctg & SIEGTETL & 17 & 21 \\
\hline & agtatag & agggga & cagaaacgctg & & 4 & \\
\hline & agtatag & agacg & gcagaaacgctg & SIETAETL & & 29 \\
\hline \multirow[t]{8}{*}{$\operatorname{Vav1}{ }^{R 63 W_{\# 3}}$} & agtat & caggg & gtgcagaaacgct & $\underline{\text { SIRGAETL }}$ & 20 & 36 \\
\hline & agtat & ccgggge & gcagaaacgctg & & 16 & \\
\hline & agtatag & ag & agtgcagaaacgctg & $\underline{\text { SIESAETL }}$ & & 16 \\
\hline & agtatag & agggaa & cagaaacgctg & SIEGTETL & 16 & 20 \\
\hline & agtatag & agggga & cagaaacgctg & & 4 & \\
\hline & agtatag & agacg & gcagaaacgctg & SIETAETL & & 12 \\
\hline & agtatag & aagggccagggggagg & tgcagaaacgctg & SIEGPGGGAETL & & 12 \\
\hline & agtatag & aaggcccaagggaag & gtgcagaaacgctg & SIEGPREGAETL & & 4 \\
\hline
\end{tabular}

${ }^{a}$ For each pool, 22-26 bacterial clones were sequenced.

${ }^{b}$ Sequence occurrence/total number of sequences performed, shown as a percentage number.

Underlined: public CDR3 found in both WT and KI.

Bold: public CDR3 found only in KI mice. 
deleted in WT mice. These clones that escape thymic selection would enhance the susceptibility to EAMG in Vav1 ${ }^{\mathrm{R} 63 \mathrm{~W}} \mathrm{KI}$ mice. In addition, $\mathrm{Vav1}^{\mathrm{R} 63 \mathrm{~W}}$ mutation favors $\mathrm{AChR}$ self-reactive $\mathrm{T}$ effector compartment without affecting AChR self-reactive Treg compartment. This imbalance between AChR reactive effector and Treg cells in favor of effector $\mathrm{T}$ cells could also contribute to the increased susceptibility of $\mathrm{Vav1}^{\mathrm{R} 63 \mathrm{~W}} \mathrm{KI}$ mice to EAMG.

Genetic association studies revealed the implication VAV1 as a risk factor for several immune-mediated diseases, such as multiple sclerosis, rheumatoid arthritis and MG (17, 44, 45). However, the underlying mechanisms still remain elusive. Our study reveals that the $\mathrm{Vavl}^{\mathrm{R} 63 \mathrm{~W}}$ variant paradigm is instrumental to expand our understanding of the immunological consequences of genetic variations of Vav1 expression and function. This model highlights the importance of Vav1 adaptor functions in the differentiation of CD $4^{+} \mathrm{T}$ cells into Th1/Th17 subsets and suggests that genetic or acquired alterations in Vav1 signaling could play a major role in susceptibility to many immune-mediated diseases, including autoimmune diseases where Th1/Th17 play a preponderant role, such as MG. Thus, our study provides a vivid example of the value of studying natural genetic variants that could bring new light to the understanding of the gene functions in physiological and pathological situations.

\section{REFERENCES}

1. Vincent A. Unravelling the pathogenesis of myasthenia gravis. Nat Rev Immunol. (2002) 2:797-804. doi: 10.1038/nri916

2. Berrih-Aknin S, Frenkian-Cuvelier M, Eymard B. Diagnostic and clinical classification of autoimmune myasthenia gravis. J Autoimmun. (2014) 4849:143-8. doi: 10.1016/j.jaut.2014.01.003

3. Phillips WD, Vincent A. Pathogenesis of myasthenia gravis: update on disease types, models, and mechanisms. F1000Res (2016) 5:1-10 doi: 10.12688/f1000research.8206.1

4. Kordas G, Lagoumintzis G, Sideris S, Poulas K, Tzartos SJ. Direct proof of the in vivo pathogenic role of the AChR autoantibodies from myasthenia gravis patients. PLoS ONE (2014) 9:e108327. doi: 10.1371/journal.pone.0108327

5. Hoch W, McConville J, Helms S, Newsom-Davis J, Melms A, Vincent A. Autoantibodies to the receptor tyrosine kinase MuSK in patients with myasthenia gravis without acetylcholine receptor antibodies. Nat Med. (2001) 7:365-8. doi: $10.1038 / 85520$

6. Pevzner A, Schoser B, Peters K, Cosma NC, Karakatsani A, Schalke B, et al. Anti-LRP4 autoantibodies in AChR- and MuSKantibody-negative myasthenia gravis. J Neurol. (2012) 259:427-35. doi: 10.1007/s00415-011-6194-7

7. Zhang B, Tzartos JS, Belimezi M, Ragheb S, Bealmear B, Lewis RA, et al. Autoantibodies to lipoprotein-related protein 4 in patients with double-seronegative myasthenia gravis. Arch Neurol. (2012) 69:445-51. doi: 10.1001/archneurol.2011.2393

8. Patrick J, Lindstrom J. Autoimmune response to acetylcholine receptor. Science (1973) 180:871-2.

9. Delpy L, Douin-Echinard V, Garidou L, Bruand C, Saoudi A, Guery JC. Estrogen enhances susceptibility to experimental autoimmune myasthenia gravis by promoting type 1-polarized immune responses. J Immunol. (2005) 175:5050-7. doi: 10.4049/jimmunol.175.8.5050

10. Giraud M, Vandiedonck C, Garchon HJ. Genetic factors in autoimmune myasthenia gravis. Ann N Y Acad Sci. (2008) 1132:180-92. doi: 10.1196/annals.1405.027

\section{AUTHOR CONTRIBUTIONS}

AS and NF conceived the project. IB, SK, MB, CP, CC, MG, and AS designed, performed the research and analyzed and interpreted the data. IB, NF, and AS prepared the figures and wrote the manuscript.

\section{ACKNOWLEDGMENTS}

We sincerely thank Anne S. Dejean, Anne Astier, Daniel Dunia and Roland Liblau for their helpful suggestions and Bernard Malissen for generating the Vav1R63W KI mice. We acknowledge the technical assistance provided by the personnel of Inserm US006 Anexplo/creffre animal facility. Flow cytometry experiments have been done at the CPTP-INSERM U1043 core facility connected to Toulouse Réseau Imagerie network. We thank Fatima-Ezzahra L'Faqihi, Valérie Duplan and Anne-Laure Iscache for technical assistance and/or for cell sorting. This work was supported by INSERM, Association Française contre les Myopathies, Fight-MG (FP7-Health-2009-242210), the Agence Nationale de la Recherche and the Aninfimip, an EquipEx program (Equipement d'Excellence) supported by the French government through the Investments for the Future program (ANR-11-EQPX-0003). AS is supported by Centre National de la Recherche Scientifique.
11. Renton AE, Pliner HA, Provenzano C, Evoli A, Ricciardi R, Nalls MA, et al A genome-wide association study of myasthenia gravis. JAMA Neurol. (2015) 72:396-404. doi: 10.1001/jamaneurol.2014.4103

12. Vandiedonck C, Capdevielle C, Giraud M, Krumeich S, Jais JP, Eymard B, et al. Association of the PTPN22*R620W polymorphism with autoimmune myasthenia gravis. Ann Neurol. (2006) 59:404-7. doi: 10.1002/ana.20751

13. Greve B, Hoffmann P, Illes Z, Rozsa C, Berger K, Weissert R, et al. The autoimmunity-related polymorphism PTPN22 1858C/T is associated with anti-titin antibody-positive myasthenia gravis. Hum Immunol. (2009) 70:5402. doi: 10.1016/j.humimm.2009.04.027

14. Gregersen PK, Kosoy R, Lee AT, Lamb J, Sussman J, McKee D, et al. Risk for myasthenia gravis maps to a (151) Pro->Ala change in TNIP1 and to human leukocyte antigen-B*08. Ann Neurol. (2012) 72:927-35. doi: 10.1002/ana.23691

15. Wang XB, Kakoulidou M, Qiu Q, Giscombe R, Huang D, Pirskanen $\mathrm{R}$, et al. CDS1 and promoter single nucleotide polymorphisms of the CTLA-4 gene in human myasthenia gravis. Genes Immun. (2002) 3:46-9. doi: 10.1038/sj.gene.6363816

16. Chuang WY, Strobel P, Gold R, Nix W, Schalke B, Kiefer R, et al. A CTLA4high genotype is associated with myasthenia gravis in thymoma patients. Ann Neurol. (2005) 58:644-8. doi: 10.1002/ana.20577

17. Avidan N, Le Panse R, Harbo HF, Bernasconi P, Poulas K, Ginzburg $\mathrm{E}$, et al. VAV1 and BAFF, via NFkappaB pathway, are genetic risk factors for myasthenia gravis. Ann Clin Transl Neurol. (2014) 1:329-39. doi: $10.1002 / \operatorname{acn} 3.51$

18. Fischer KD, Zmuldzinas A, Gardner S, Barbacid M, Bernstein A, Guidos C. Defective T-cell receptor signalling and positive selection of Vav-deficient $\mathrm{CD}^{+}{ }^{+} \mathrm{CD}^{+}{ }^{+}$thymocytes. Nature (1995) 374:474-7. doi: 10.1038/374474a0

19. Tarakhovsky A, Turner M, Schaal S, Mee PJ, Duddy LP, Rajewsky K, et al. Defective antigen receptor-mediated proliferation of $\mathrm{B}$ and $\mathrm{T}$ cells in the absence of Vav. Nature (1995) 374:467-70. doi: 10.1038/374467a0

20. Zhang R, Alt FW, Davidson L, Orkin SH, Swat W. Defective signalling through the T- and B-cell antigen receptors in lymphoid cells lacking the vav proto-oncogene. Nature (1995) 374:470-3. doi: 10.1038/374470a0 
21. Turner M, Mee PJ, Walters AE, Quinn ME, Mellor AL, Zamoyska R, et al. A requirement for the Rho-family GTP exchange factor Vav in positive and negative selection of thymocytes. Immunity (1997) 7:451-60.

22. Tybulewicz VL. Vav-family proteins in T-cell signalling. Curr Opin Immunol. (2005) 17:267-74. doi: 10.1016/j.coi.2005.04.003

23. Fischer KD, Kong YY, Nishina H, Tedford K, Marengere LE, Kozieradzki I, et al. Vav is a regulator of cytoskeletal reorganization mediated by the T-cell receptor. Curr Biol. (1998) 8:554-62.

24. Costello PS, Walters AE, Mee PJ, Turner M, Reynolds LF, Prisco A, et al. The Rho-family GTP exchange factor Vav is a critical transducer of T cell receptor signals to the calcium, ERK, and NF-kappaB pathways. Proc Natl Acad Sci USA. (1999) 96:3035-40.

25. Saveliev A, Vanes L, Ksionda O, Rapley J, Smerdon SJ, Rittinger K, et al. Function of the nucleotide exchange activity of vav1 in T cell development and activation. Sci Signal. (2009) 2:ra83. doi: 10.1126/scisignal.2000420

26. Kassem S, Gaud G, Bernard I, Benamar M, Dejean AS, Liblau R, et al. A natural variant of the $\mathrm{T}$ cell receptor-signaling molecule Vav1 reduces both effector T cell functions and susceptibility to neuroinflammation. PLoS Genet. (2016) 12:e1006185. doi: 10.1371/journal.pgen.1006185

27. Colacios C, Casemayou A, Dejean AS, Gaits-Iacovoni F, Pedros C, Bernard I, et al. The p.Arg63Trp polymorphism controls Vav1 functions and Foxp3 regulatory T cell development. J Exp Med. (2011) 208:2183-91. doi: $10.1084 /$ jem. 20102191

28. Lindstrom J, Einarson B, Tzartos S. Production and assay of antibodies to acetylcholine receptors. Methods Enzymol. (1981) 74 Pt C:432-60.

29. Saoudi A, Bernard I, Hoedemaekers A, Cautain B, Martinez K, Druet P, et al. Experimental autoimmune myasthenia gravis may occur in the context of a polarized Th1- or Th2-type immune response in rats. J Immunol. (1999) 162:7189-97.

30. Huang D, Shi FD, Giscombe R, Zhou Y, Ljunggren HG, Lefvert AK. Disruption of the IL-1beta gene diminishes acetylcholine receptor-induced immune responses in a murine model of myasthenia gravis. Eur J Immunol. (2001) 31:225-32. doi: 10.1002/1521-4141(200101)31:1<225::AID-IMMU225>3.0.CO;2-0

31. Wang W, Ostlie NS, Conti-Fine BM, Milani M. The susceptibility to experimental myasthenia gravis of STAT $6^{-1-}$ and STAT4 ${ }^{-/-}$BALB/c mice suggests a pathogenic role of Th1 cells. J Immunol. (2004) 172:97-103. doi: 10.4049/jimmunol.172.1.97

32. Balasa B, Deng CS, Lee J, Bradley LM, Dalton DK, Christadoss P, et al. Interferon gamma (IFN-gamma) is necessary for the genesis of acetylcholine receptor-induced clinical experimental autoimmune myasthenia gravis in mice. J Exp Med. (1997) 186:385-91. doi: 10.1084/jem.186.3.385

33. Moiola M, Galbiati F, Martino G, Amadio S, Brambilla E, Comi G, et al. IL-12 is involved in the induction of experimental autoimmune myasthenia gravis, an antibody-mediated disease. Eur J Immunol. (1998) 28:2487-97.

34. Roche JC, Capablo JL, Larrad L, Gervas-Arruga J, Ara JR, Sanchez $A$, et al. Increased serum interleukin-17 levels in patients with myasthenia gravis. Muscle Nerve (2011) 44:278-80. doi: 10.1002/mus. 22070
35. Schaffert H, Pelz A, Saxena A, Losen M, Meisel A, Thiel A, et al. IL17-producing $\mathrm{CD} 4(+) \mathrm{T}$ cells contribute to the loss of B-cell tolerance in experimental autoimmune myasthenia gravis. Eur J Immunol. (2015) 45:1339-47. doi: 10.1002/eji.201445064

36. Cao Y, Amezquita RA, Kleinstein SH, Stathopoulos P, Nowak RJ, O'Connor KC. Autoreactive T cells from patients with myasthenia gravis are characterized by elevated IL-17, IFN-gamma, and GM-CSF and diminished IL-10 production. J Immunol. (2016) 196:2075-84. doi: 10.4049/jimmunol.1501339

37. Aguilo-Seara G, Xie YC, Sheehan J, Kusner LL, Kaminski HJ. Ablation of IL17 expression moderates experimental autoimmune myasthenia gravis disease severity. Cytokine (2017) 96:279-85. doi: 10.1016/j.cyto.2017.05.008

38. Yamane H, Paul WE. Early signaling events that underlie fate decisions of naive CD4(+) T cells toward distinct T-helper cell subsets. Immunol Rev. (2013) 252:12-23. doi: 10.1111/imr.12032

39. Tubo NJ, Jenkins MK. TCR signal quantity and quality in CD4(+) $\mathrm{T}$ cell differentiation. Trends Immunol. (2014) 35:591-6. doi: 10.1016/j.it.2014.09.008

40. van Panhuys N, Klauschen F, Germain RN. T-cell-receptor-dependent signal intensity dominantly controls $\mathrm{CD} 4(+) \mathrm{T}$ cell polarization in vivo. Immunity (2014) 41:63-74. doi: 10.1016/j.immuni.2014.06.003

41. Jorritsma PJ, Brogdon JL, Bottomly K. Role of TCR-induced extracellular signal-regulated kinase activation in the regulation of early IL-4 expression in naive CD4(+) T cells. J Immunol. (2003) 170:2427-34. doi: 10.4049/jimmunol.170.5.2427

42. Yamane $\mathrm{H}$, Zhu JF, Paul WE. Independent roles for IL-2 and GATA-3 in stimulating naive $\mathrm{CD} 4(+) \mathrm{T}$ cells to generate a Th2-inducing cytokine environment. J Exp Med. (2005) 202:793-804. doi: 10.1084/jem.20051304

43. Liu X, Bosselut R. Duration of TCR signaling controls CD4-CD8 lineage differentiation in vivo. Nat Immunol. (2004) 5:280-8. doi: 10.1038/ni1040

44. Jagodic M, Colacios C, Nohra R, Dejean AS, Beyeen AD, Khademi M, et al. A role for VAV1 in experimental autoimmune encephalomyelitis and multiple sclerosis. Sci Transl Med. (2009) 1:10ra21. doi: 10.1126/scitranslmed.3000278

45. Guerreiro-Cacais AO, Norin U, Gyllenberg A, Berglund R, Beyeen AD, PetitTeixeira E, et al. VAV1 regulates experimental autoimmune arthritis and is associated with anti-CCP negative rheumatoid arthritis. Genes Immun. (2017) 18:48-56. doi: 10.1038/gene.2016.49

Conflict of Interest Statement: The authors declare that the research was conducted in the absence of any commercial or financial relationships that could be construed as a potential conflict of interest.

Copyright (c) 2018 Bernard, Sacquin, Kassem, Benamar, Colacios, Gador, Pérals, Fazilleau and Saoudi. This is an open-access article distributed under the terms of the Creative Commons Attribution License (CC BY). The use, distribution or reproduction in other forums is permitted, provided the original author(s) and the copyright owner(s) are credited and that the original publication in this journal is cited, in accordance with accepted academic practice. No use, distribution or reproduction is permitted which does not comply with these terms. 